Article

\title{
Plant-Soil Feedback Effects on Germination and Growth of Native and Non-Native Species Common across Southern California
}

\author{
Manya Singh ${ }^{1}$ and Wallace M. Meyer III ${ }^{2, *}$ \\ 1 W.M. Keck Science Department, Claremont McKenna, Pitzer, and Scripps Colleges, Claremont, CA 91711, \\ USA; msingh@hawaii.edu \\ 2 Department of Biology, Pomona College, Claremont, CA 91711, USA \\ * Correspondence: Wallace_meyer@pomona.edu
}

Received: 13 April 2020; Accepted: 28 May 2020; Published: 30 May 2020

\begin{abstract}
Changes in plant assemblages can influence biotic and abiotic soil conditions. These changes can cause plant-soil feedbacks that can inhibit or facilitate plant germination and growth. Here, we contribute to a growing literature examining plant-soil feedbacks in the endangered sage scrub ecosystem by examining the germination and growth of Artemisia californica, the dominant native shrub species in the ecosystem, in soil conditioned by two widespread plant invaders (Brassica nigra, Bromus madritensis ssp. rubens), and the germination and growth of these invasive species in conspecific and heterospecific soils. Our findings suggest that: (i) A. californica soils can limit establishment of some species (B. nigra) but not others (B. madritensis), (ii) A. californica soil conditions reduce growth of all plant species, and (iii) non-natives are negatively impacted by soil microbes, but in some contexts can do better in heterospecific soil. As our findings were often incongruent with other studies that examined interactions among similar species at other sites, we suggest that we are at our infancy of understanding these complex interactions, and that developing a predictive framework for understanding plant soil feedbacks in the sage scrub ecosystem involves understanding how various plant species respond in different soil contexts within the ecosystem.
\end{abstract}

Keywords: sage scrub; microbial community; Artemisia californica; non-native grass; mustards; enemy release hypothesis; invasion

\section{Introduction}

Changes in plant assemblages can influence multiple aspects of a soil environment, including both soil abiotic (e.g., nutrient concentrations, $\mathrm{pH}$ ) and biotic (e.g., composition and abundance of microbial assemblages) conditions [1-4]. These changes in soil conditions can cause feedbacks, known as plant-soil feedbacks, that can inhibit or facilitate plant germination and growth, but the direction and magnitude of the feedback depends on both the plant species and the soil context being examined [3,5-7]. When trying to understand how plant-soil feedbacks influence invasion processes, we are often interested in examining whether: (i) native species modify soils in ways that can restrict establishment and spread of invasive species-e.g., biotic resistance [8-10]; (ii) successful plant invaders are released from soil pathogens in their invasive range (enemy release hypothesis) [11,12]; and (iii) non-native species alter soil conditions to reinforce their dominance $[13,14]$. As these interactions are multifaceted, research focused on key species in ecological contexts threatened by the spread of invasive species is needed, as it may provide valuable insights into understanding invasion processes and how to improve restoration and conservation efforts [15-17]. 
In southern California, substantial portions of the endangered California sage scrub (hereafter, sage scrub) ecosystem, a low elevation, shrub-dominated ecosystem type typified by the shrub Artemisia californica [18], are being type-converted to non-native grasslands, or forblands, dominated by invasive mustard species [2,19]. Estimates suggest that since 1930, approximately $50 \%$ of sage scrub areas in southern California not converted to urban/suburban habitats have become dominated by non-native grasses, mostly European in origin $[17,19]$. In addition to non-native grasses, non-native mustard species (Brassica nigra, Hirschfeldia incana, and others) are also becoming increasingly widespread and can form monotypic stands in disturbed low elevation areas of southern California [2,20,21]. Increases in N-deposition and other disturbances, such as fire, have facilitated the spread and increased the abundances of these invasive annuals $[19,22,23]$. Invasive grasses and forbs reduce fire return intervals as they increase ignition probabilities in the hot summer months when they are dead, facilitating further loss of sage scrub and type-conversion to invasive habitats throughout the region, as non-native species are often the first to colonize an area after a disturbance [24,25].

Previous studies in southern California suggest that understanding plant-soil feedbacks may be important if we intend to understand invasion processes and restore the sage scrub ecosystem. For example, Bozzolo and Lipson [26] demonstrated that growth of two abundant and widespread native shrubs species that typify the sage scrub ecosystem, Artemisia californica and Eriogonum fasciculatum, was enhanced by microbes in sage scrub soil. However, in the same study [26], growth of invasive annuals was either reduced (Centaurea melitensis) or was unaffected (Bromus madritensis, Brassica nigra) by sage scrub soil microbes. These results contrast with other studies $[7,27]$ in the sage scrub ecosystem. For instance, Yelenik and Lipson [7] demonstrate that growth of A. californica and another invasive annual grass, Avena barbata, was enhanced in heterospecific, not conspecific soil. Additionally, Valliere and Allen [27] report that growth of two invasive annual species, Bromus diandrus and Centaurea melentensis, was increased in soil from the sage scrub system compared with sterilized soil. Recently, Pickett et al. [3] demonstrated that an invasive bunch grass (Phalaris aquatia) changes soil microbial composition and reduces A. californica fitness, though two other common native shrubs, Baccharis pilularis and Salvia leucopylla, were not influenced by these changes. Combined, these results highlight the complexities associated with understanding plant-soil feedbacks, as interactions are plant-species and soil-context specific.

In this study, we examined germination and growth of $A$. californica in soil conditioned by widespread plant invaders not previously examined, and by examining germination and growth of these invasive species in conspecific and heterospecific soils. Specifically, we examined whether germination and early growth of native A. californica (shrub) and non-native Bromus madritensis ssp. rubuns (non-native grass), hereafter Bromus madritensis, and Brassica nigra (non-native mustard), are influenced by soil conditioned by widespread native and non-native plant species: A. californica, B. madritensis, and Hirschfeldia incana (another non-native mustard). To do this, we compared germination and growth of plants using two "self vs. other" soil approaches [28]: (i) sterilizing half of each soil type collected and comparing differences in germination and growth of all plant species in sterilized (microbial assemblages excluded) and unsterilized soil, and (ii) comparing differences in growth for each plant species in soil conditioned by different plant species. Based on observations that these invasive species often dominate the plant assemblages in areas where they become established and have trouble establishing populations in areas with mature sage scrub [1,2], we hypothesized that: (i) soil conditioned by A. californica reduces germination and/or growth rates of invasive plant species (e.g., biotic resistance hypothesis) and sterilization enhances germination and growth of these species; (ii) A. californica has lower growth rates in soil conditioned by invasive species, and sterilization of soil from invasive habitats enhances A. californica growth; and (iii) germination and growth of widespread invaders (Bromus madritensis and Brassica nigra) are reduced in soils conditioned by heterospecific non-natives. 


\section{Materials and Methods}

\subsection{Site Description and Soil Collection}

All soil was collected from the Robert J. Bernard Biological Field Station (BFS) in Claremont, California, which is located at the eastern edge of Los Angeles County. Sage scrub at the BFS is dominated by drought-deciduous and drought-tolerant evergreen shrubs, including A. californica, Eriodictyon trychocalyx, Salvia apiana, and E. fasciculatum. Non-native grasses and mustards are rare in in undisturbed sage scrub areas of the BFS and are typically found in areas with a history of disturbance and along edges of roads. At the BFS, non-native grasslands and mustardlands have existed for at least forty years (unpublished data), providing an opportunity to explore patterns in soils after they have been influenced by these species for a significant period of time. Grasslands are dominated in different areas by Bromus diandrus and Bromus madritensis, both European grasses. At our site, we have red brome, Bromus madritensis ssp. rubuns, and not foxtail chess, B. madritensis ssp. madritensis. These two species have different ploidy levels [29] and may not be subspecies. Mustardlands are found in areas that have been heavily impacted in the past by human activity (footprint of removed structure and large soil movement) and are dominated by Hirschfeldia incana, the short-pod mustard, though other non-native mustards are present at the BFS, including: Brassica nigra, Brassica rapa, Brassica fruticulosa, Brassica tournefortii (significant control efforts limit this species' spread and the abundance of this species), Sisymbrium orientale, and Sisymbrium irio. No fires had been reported in these non-native areas for 40 years. Fires occurred in 2013 and 2017 in a transitional habitat-one with non-native grasses and recovering sage scrub shrubs, but not in the sage scrub, non-native grassland, or mustard areas where soil was collected [30]. Care was taken to collect soil from under each plant species and avoid areas influenced by other native and non-native plants (particularly Erodium spp. and Amsinckia intermedia in the grassland). Leguminous plants are rare in unburned areas of the BFS. Collection of soil from one site was critical to control for the effects of nitrogen (N) deposition, as $\mathrm{N}$ availability plays a key role in both plant feedbacks and the distribution and growth of many of these plant species [22,27], and to control for the influences of different soil properties [2]. Nitrogen deposition is high at our site ( $>25 \mathrm{~kg}$ per year) [31], so care should be taken when extrapolating our findings to sites with lower N-deposition. Wheeler et al. [4] and Caspi et al. [1,2] highlight that soil from the BFS does not differ across habitat types other than with regard to $\mathrm{pH}$, which is lower in the sage scrub habitat relative to the non-native grassland. However, soil microbial assemblages do differ between the sage scrub and non-native grassland habitats at the BFS, and elsewhere [1,32].

\subsection{Experimental Design}

We had six soil treatments, which consisted of sterilized and unsterilized soil collected from under A. californica, B. madritensis, and H. incana from the BFS. Particular care was taken to ensure that soil was collected from under each plant species. In the grassland, soil was collected from areas with dense concentrations of B. madritensis, though Bromus diandrus was almost always present. Hereafter, we use soil condition to refer to sterilized and unsterilized soil, and soil origin to refer to the plant species under which the soil was collected. Soil was sterilized by autoclaving half of each soil type at $121^{\circ} \mathrm{C}$ for $30 \mathrm{~min}$, twice. Autoclaving soils and steaming soil, a process similar to autoclaving, does not influence available $\mathrm{N}[26,27]$. To confirm that the sterilization process killed the microbial community and to examine whether this process influenced soil nutrients, we collected two soil sample types systematically from each soil treatment before initiation of the experiment. First, we collected six $50 \mathrm{~mL}$ subsamples of soil systematically from each soil treatment, while we were filling containers (see below). Subsamples from each soil type were placed into the same bag, homogenized, and sent to Earthfort Laboratories (Corvallis, Oregon) to examine active and total fungi. Total fungi $(\mu \mathrm{g} / \mathrm{g}$ ) was determined directly using microscopy by converting length and width measurements. Active fungi $(\mu \mathrm{g} / \mathrm{g})$ was quantified after staining samples with fluorescein diacetate which binds and fluoresces to metabolically active fungi [33]. Second, we also systematically collected six $30 \mathrm{~mL}$ samples from each 
soil treatments to examine carbon and nitrogen concentrations using an Elementar vario Micro cube elemental analyzer (Mt. Laurel, NJ, USA).

In each soil treatment, we grew three plant species: A. californica, B. madritensis, and B. nigra. Brassica nigra was grown due to availability of commercially grown, viable seeds. Both $B$. nigra and H. incana are non-mycorrhizal and have similar phylogenies [34]. Artemisia californica and B. madritensis seeds were collected from the BFS. In total, we created ten replicates for each plant species in the six soil treatments (180 total replicates). Each replicate consisted of soil (approximately $50 \mathrm{~mL}$ ) being placed in a Ray Leach container ${ }^{\mathrm{TM}}$ (RCL3; $2.5 \mathrm{~cm}$ diameter, $12 \mathrm{~cm}$ depth) stirring the soil in between to homogenize the soil and adding one seed and covering each with $\sim 0.5$ to $1 \mathrm{~cm}$ of soil. All containers were randomly placed into three container holders, which we placed in open area of the Pomona College green house at $24-26^{\circ} \mathrm{C}$ during the day and $21-24{ }^{\circ} \mathrm{C}$ at night. The container holders were in partial sun. We rotated and shuffled their positions daily to prevent differences in germination and growth being due to their positions in the greenhouse. We watered plants once daily with reverse osmosis water using the mist function on a watering wand held for $150 \mathrm{~s}$ at about $10 \mathrm{~cm}$ above soil surface level of each container holder. However, on the first day, we completed three cycles of the daily watering routine and ensured water penetration.

Growth and germination experiments ran from 29 May 2018 to 7 August 2018. We monitored germination for three weeks by checking all containers daily. We removed all non-target species in unsterilized soil (17 total). At the end of the three-week germination period, we transplanted seedlings recently germinated in a moist paper towel to containers where no germination had occurred. For each replicate, we monitored the growth of the individual for 7-9 weeks. Upon termination of the experiment, we carefully extracted each individual plant from its soil for growth analysis. Aboveground biomass was separated from belowground biomass by marking the soil level, before brushing and washing the soil away, and cutting the individual at the mark. Differences in below ground biomass were not examined, as we observed root loss through our sieves. The aboveground portion of each plant was dried in an oven at $40{ }^{\circ} \mathrm{C}$ for at least $72 \mathrm{~h}$ and weighed. Growth rate was calculated by dividing the weight by number of weeks since germination.

\subsection{Analyses}

We first examined whether autoclaving influenced soil biotic and abiotic conditions. To examine whether autoclaving reduced abundances and activities of soil fungi in the three soil types, we report data from batch samples collected from each soil treatment, testing the hypothesis that autoclaving of the soil reduced abundances and activities of microbes using two response variables (total and active fungi). To test whether soil total $\mathrm{C}$ and $\mathrm{N}$ concentrations differed among soil origins and conditions, we ran a two-factor PERMANOVA (permutation based ANOVA) using soil origin and soil condition as factors for each nutrient using similarity matrices calculated using Euclidean similarity coefficient. Following significant PERMANOVA results for either soil origin, soil condition, or a soil origin * soil condition interaction, we conducted pairwise comparisons to determine whether nutrient concentrations differed among soil origins via comparing nutrient concentrations among unsterilized soil treatments from different origins and from different soil origins using both sterilized and unsterilized soil. In addition, pairwise comparisons were used to examine whether nutrient concentrations differed between soil conditions from each soil origin.

Because germination data is binomial, and because we were specifically interested in testing whether (i) there were differences in germination rates between soil conditions (sterilized and unsterilized) for each plant species in soil from each soil origin, and (ii) whether germination rates differed for each plant species among soil origins, we used a combination of log-odds ratio tests and Chi-squared tests. First, we ran nine individual log-odds ratio tests examining whether germination differed between sterilized and unsterilized soils from each origin and for each plant species. Because of the high number of paired tests but relatively low sample sizes ( $n=10$ for each soil condition) for each test, we did not reduce $\alpha$-values for multiple testing here and report differences among treatments 
using a $\alpha$ of 0.05 . Second, we ran three Chi-squared tests to test whether germination rates differed among soil origins (unsterilized soils) for each plant species.

To examine whether growth differed among plant species, soil origins, and soil conditions, we ran one three-factor PERMANOVA. This PERMANOVA used a similarity matrix calculated using the Euclidean similarity coefficient. Pairwise comparisons were run following any significant PERMOVA results for any treatment or interaction term. We also ran three additional PERMANOVA tests to test whether growth differed among soil origins (using unsterilized soil only) for each plant species using a $\alpha=0.017$. All PERMANOVAs were run using the program PRIMER-E with the PERMANOVA+ add on [35].

\section{Results}

\subsection{Impacts of Sterilization on Biotic and Abiotic Soil Conditions}

Sterilization reduced fungal abundances and activity in all soil origins (Table 1), with fungal activity being reduced to 0 in all sterilized treatments. We did not measure bacterial activity and abundance.

Table 1. Active and total fungal concentrations $(\mu \mathrm{g} / \mathrm{g})$ in six soil treatments. Soil was collected under three different plant species (soil origins), and soil from each origin was either sterilized or kept unsterilized (soil conditions).

\begin{tabular}{cccc}
\hline Active or Total Fungi & \multicolumn{3}{c}{ Soil Origin } \\
\cline { 2 - 4 } Soil Condition & A. californica & B. madritensis & H. incana \\
\hline Active Fungi & & & \\
Unsterilized & 7.83 & 2.94 & 0 \\
Sterilized & 0 & 0 & 0 \\
Total Fungi & & 406.21 & 228.68 \\
Unsterilized & 240.71 & 122.13 & 121.50 \\
Sterilized & 114.31 & & \\
\hline
\end{tabular}

Both $\mathrm{C}\left(\mathrm{F}_{2,30}=25.26, p=0.001\right)$ and $\mathrm{N}\left(\mathrm{F}_{2,30}=7.87, p=0.001\right)$ concentrations differed among soil origins (Figure 1). Soil C concentrations were elevated in soils from A. californica and H. incana relative to soils from $B$. madritensis when making comparisons among soil origins using both sterilized and unsterilized soil (Figure 1), which is consistent with patterns observed in soil C in these habitat types across the region [2]. Pairwise comparisons that compared differences in $\mathrm{C}$ among soil origins using unsterilized soils found similar patterns, but the percentage of $C$ did not differ between $A$. californica and B. madritensis soil origins. Soil $\mathrm{N}$ was higher in $H$. incana soil than B. madritensis soil, but $A$. californica soil did not differ in $\mathrm{N}$ concentration from either H. incana or B. madritensis soils. Patterns for $\mathrm{N}$ were similar among soil origins when comparing $\mathrm{N}$ concentrations using only unsterilized soil or including both sterilized and unsterilized soils (Figure 1$)$. Soil $\mathrm{C}$ differed among soil conditions $\left(\mathrm{F}_{1,30}=12.52\right.$, $p=0.001$ ), with $C$ being elevated in the sterilized treatment. However, pairwise comparisons examining soil $C$ in sterilized and unsterilized soil from each soil origin show that soil $C$ is only elevated in sterilized H. incana soils, but not $A$. californica or B. madritensis soil (Figure 1). Soil conditions did not differ in $\mathrm{N}$ concentrations $\left(\mathrm{F}_{1,30}=3.90, p=0.055\right)$, but there was a significant soil condition $\mathrm{x}$ soil origin interaction $\left(\mathrm{F}_{2,30}=4.00, p=0.027\right)$. Pairwise comparisons did not reveal differences in $\mathrm{N}$ concentrations between soil conditions for any soil origin (Figure 1). 

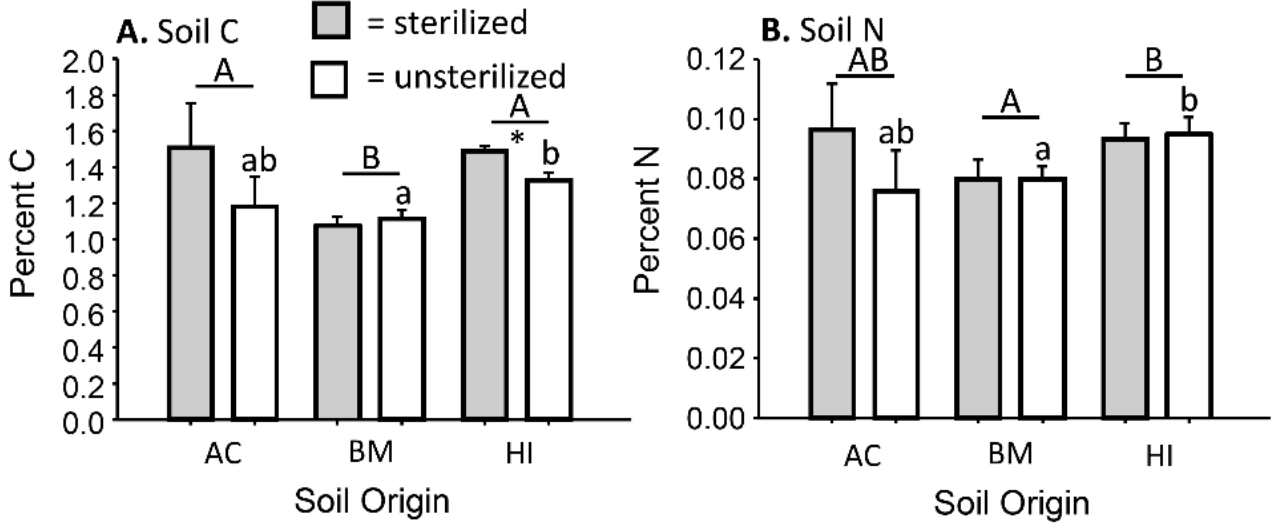

Figure 1. Nutrient concentrations (A soil C; B soil N) among soil origins (AC, Artemisia californica; BM, Bromus madritensis; HI, Hirschfeldia incana) and between soil conditions within soil origins. Capital letters indicate differences in nutrient concentrations among soil origins. Lower case letters represent differences in nutrient concentrations in unsterilized soil among soil origins, and * indicate when nutrient concentrations differed between soil conditions in each soil origin.

\subsection{Influence of Soil Treatment on Germination Rates}

Brassica nigra germination was greater in sterilized soil relative to unsterilized soil from all three soil origins (Figure 2; A. californica soil, $\mathrm{Z}=2.88, p=0.0039 ; B$. madritensis soil, $\mathrm{Z}=2.106 ; p=0.035$; $H$. incana soil $Z=2.720, p=0.0065)$. Germination rates did not differ between soil conditions for B. madritensis or $A$. californica in soil from any soil origin. Germination rates did not differ among soil origins for any plant species (A. californica $\chi^{2}=0.952, p=0.62$; B. madritensis $\chi^{2}=2.4, p=0.30$ ); B. nigra germination in unsterilized soil was too low to run statistical tests with.

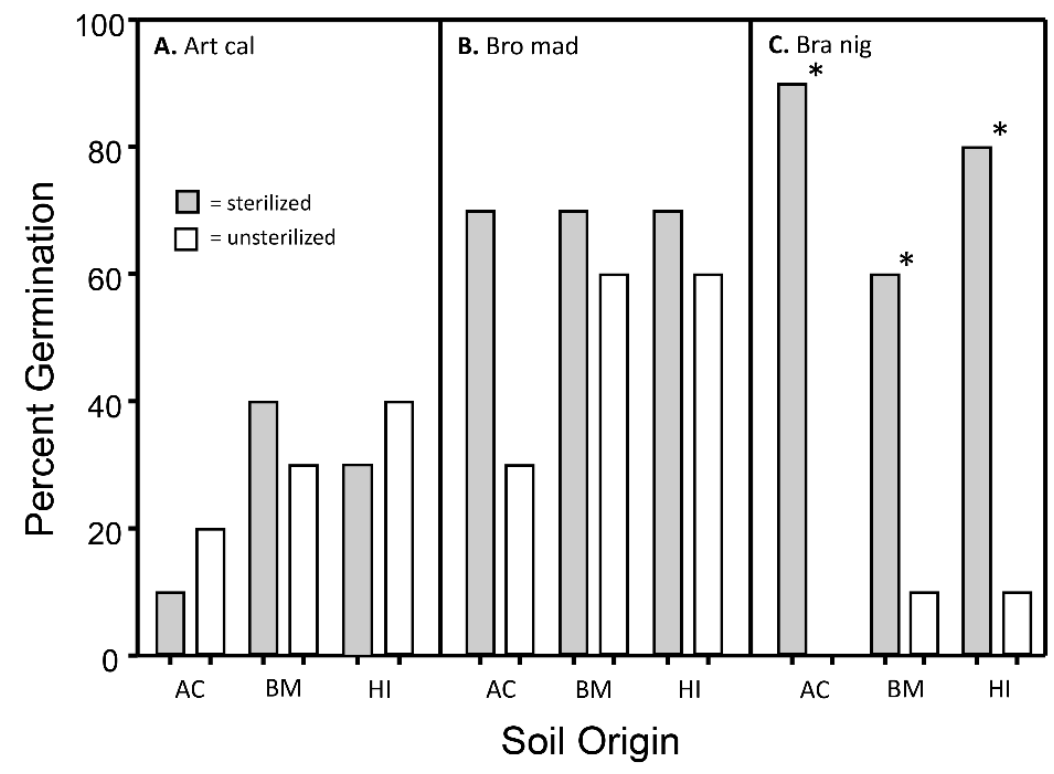

Figure 2. Germination rates for the three plant species (Art cal, A. californica; Bro mad, B. madritensis; Bra nig, Brassica nigra) among soil origins (AC, A. californica; BM, B. madritensis; HI, H. incana) and between soil conditions within soil origins. ${ }^{*}$ indicate when germination differed between soil conditions for each plant species in each soil origin. Germination did not differ among soil origins for any plant species.

\subsection{Differences in Growth among Plant Species, Soil Origins, and Soil Conditions}

Growth differed among plant species $\left(\mathrm{F}_{2,122}=41.04, p=0.0001\right)$, soil origin $\left(\mathrm{F}_{2,122}=25.41\right.$, $p=0.0001)$, and soil condition $\left(\mathrm{F}_{1,122}=74.55, p=0.0001\right.$; Figure 3$)$. There were also significant plant 
species-soil origin $\left(\mathrm{F}_{4,122}=2.87, p=0.024\right)$ and plant species-soil condition $\left(\mathrm{F}_{2,122}=6.01, p=0.0034\right)$ interactions. Pairwise comparisons revealed that $B$. nigra grew faster than $A$. californica $\left(\mathrm{F}_{1,81}=6.58\right.$, $p=0.0001)$ and B. madritensis $\left(\mathrm{F}_{1,85}=7.46, p=0.0001\right)$, while growth of $A$. californica and B. madritensis did not differ $\left(\mathrm{F}_{1,78}=0.20, p=0.84\right)$. Growth was reduced in A. californica soils relative to $H$. incana $\left(\mathrm{F}_{1,82}=6.59, p=0.0001\right)$ and B. madritensis $\left(\mathrm{F}_{1,76}=6.38, p=0.0001\right)$ soils, but growth did not differ for plants grown in $H$. incana and B. madritensis soils $\left(\mathrm{F}_{1,86}=1.55, p=0.13\right)$. Growth of $B$. nigra was elevated in sterilized soils relative to unsterilized soils from all three soil origins (Figure 3). Bromus madritensis growth was elevated in sterilized soil from two soil origins: B. madritensis and H. incana. A. californica growth was enhanced when B. madritensis soil was sterilized (Figure 3). While growth of A. californica did not differ among treatments with unsterilized soil from different soil origins, growth for bot B. madritensis and B. nigra was elevated in H. incana soil, though growth of B. nigra did not differ in soil from H. incana and B. madritensis soil origins, as it did for B. madritensis (Figure 3).

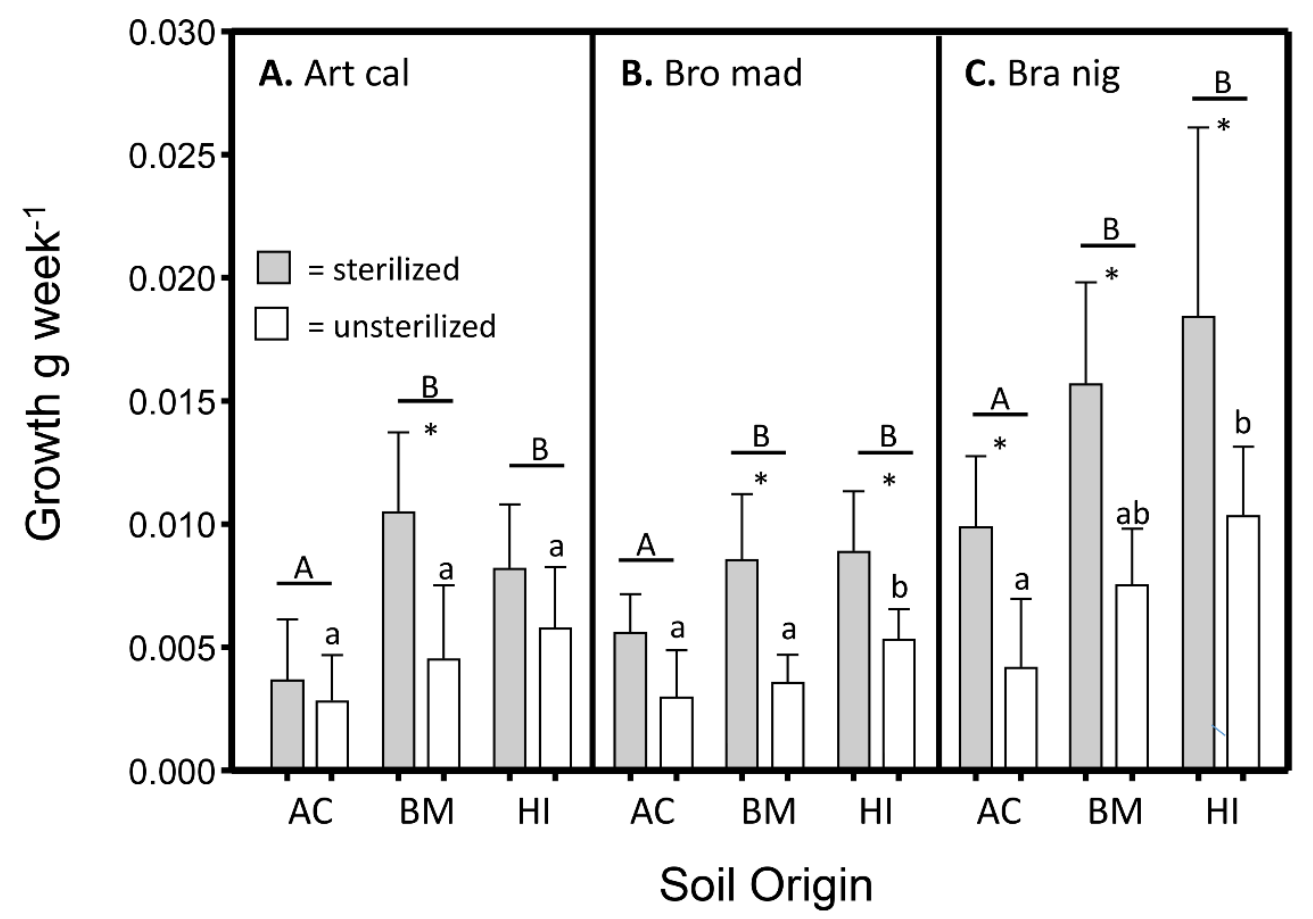

Figure 3. Growth of the three plant species (Art cal, A. californica; Bro mad, B. madritensis; Bra nig, Brassica nigra) among soil origins (AC, A. californica; BM, B. madritensis; HI, H. incana) and between soil conditions within soil origins. Capital letters indicate differences in growth among soil origins for the three plant species. Lower case letters represent differences in growth in unsterilized soil across the three soil origins for the three plant species, and * indicate when growth differed between soil conditions for each plant species in each soil origin.

\section{Discussion}

Our findings, combined with those of other studies examining plant-soil feedbacks and invasion in the sage scrub ecosystem, highlight that the roles of plant-soil feedbacks in A. californica soil are species specific. For example, our results support the idea that $A$. californica soil can limit the establishment of B. nigra, but $B$. madritensis is not impacted. In this study, germination rates of $B$. nigra were reduced in unsterilized A. californica soil compared to sterilized soil, highlighting that soil microbes may represent a barrier to establishment of this species into the sage scrub ecosystem. Artemisia californica soil also reduced growth of $B$. nigra, as growth of $B$. nigra improved with sterilization, and was elevated in unsterilized $H$. incana soil relative to unsterilized $A$. californica soil. In contrast, sterilization of A. californica soil did not influence germination or growth of $B$. madritensis, and growth of $B$. madritensis was equivalent in unsterilized A. californica and B. madritensis soil. Similarly, Bozzolo and Lipson [26] 
found that growth of non-natives was either reduced or unaffected by soil conditioned by A. californica. However, Valliere and Allen [27] and Yelenik and Levine [7] found improved growth of non-natives in sage scrub and A. californica conditioned soil. Combined, results suggest that soil conditioned by A. californica and other shrubs in the sage scrub ecosystem can provide ecological resistance against, have no effect on, or potentially facilitate the establishment and spread of non-natives, but the direction and strength depend on the identity of the invader.

In contrast to our hypothesis, growth of $A$. californica was not influenced by soil conditioned by the two invasive annuals. In other studies, growth of $A$. californica was enhanced in soil conditioned by A. barbata [7], but reduced in soil conditioned by Phalaris aquatia, an invasive bunch grass [3]. Pickett et al. [3] also demonstrated that $A$. californica growth was reduced in soil once dominated by P. aquatia, even 11 years after restoration of the invaded area to sage scrub. As such, these invasive species can change the soil microbial assemblages, creating legacy effects that remain even after the invasive species have been removed, highlighting that the history of a site is an important consideration of any plant-soil feedback study. However, two other common native shrubs in the sage scrub ecosystem, Baccharis pilularis and Salvia leucopylla, were not influenced by changes associated with P. aquatia establishment [3], suggesting that plant-soil feedbacks for native shrub species in soils conditioned by invasive species are also species specific.

Predicting plant-soil feedbacks across the sage scrub ecosystem also requires understanding how various plant species respond in different soil contexts, as soil abiotic and biotic conditions change across spatial and temporal gradients within the sage scrub ecosystem $[1,2,36]$. In contrast to our findings, Bozzolo and Lipson [26] found that growth of B. nigra growth was unaffected by soil microbes in A. californica soil, and Valliere and Allen [27] found that growth of a closely related grass species (Bromus diandrus) was elevated in sage scrub soils. Similarly, Bozzolo and Lipson [26] found that A. californica and another widespread sage scrub shrub species, E. fasiculatum, were enhanced by microbes in sage scrub soil, whereas we found no differences in A. californica germination and growth among sterilized and unsterilized soils. Differences between studies could be related to differences in the experimental designs of the studies, as Bozzolo and Lipson [26] fertilized all their soil treatments with $\mathrm{N}$ and $\mathrm{Ca}$, which was not done here, and Valliere and Allen [27] collected "sage scrub" soils which may have different microbial communities than those specifically collected from directly under A. californica plants. Differences may also be associated with variations in soil microbial assemblages, as all sites were $>30 \mathrm{~km}$ apart. Fungal and bacterial assemblages in soils differ greatly among sites within the sage scrub ecosystem, though the functional ramifications of these differences have not been assessed $[1,32,37]$. In addition to spatial impacts on soil microbial assemblages, significant inter-annual shifts in microbial assemblages are also significant [36]. As such, multi-site studies are required to understand how spatial and temporal changes influence both microbial assemblages and plant-soil feedbacks across the endangered sage scrub ecosystem. Including sequencing methodologies, which are rarely included in plant-soil feedback studies (but see [3,6]), would enhance our ability to identify soil pathogens that impact different plant species. These results highlight the complexity associated with understanding plant-soil feedbacks in the endangered sage scrub ecosystem and suggest that we are only at the infancy of understanding these interactions.

However, the assumption that non-natives are released from soil pathogens in their non-native range (e.g., enemy release hypothesis) is not supported. If the enemy release hypothesis was supported, we would have expected no difference in germination and growth between sterilized and unsterilized soil for non-native plant species in all soil origins. Instead, we observed patterns that suggest that southern California soil microbiomes contain pathogens that negatively influence non-native species in a host of soil environments. The most compelling evidence for the presence of soil pathogens is associated with B. nigra germination, which was strongly impacted by sterilization in all three soil origins. Brassica nigra germination ranged from $60 \%$ to $90 \%$ in sterilized soil, but only $0-10 \%$ in unsterilized soils from all three origins, suggesting that soil microbes can play a significant role in the success of some non-native species. Soil pathogens elsewhere have been shown to increase seed 
mortality, and reduced germination can limit plant establishment $[6,9]$. Reduced growth of B. nigra in sterilized soil relative to unsterilized soil in all three soil origins and reduced B. madritensis growth in sterilized soil in two soil origins further supports this assertion, and suggests that interactions with soil microbes in southern California are often deleterious to non-natives, and not benign, as the enemy release hypothesis posits.

While we predicted that soil microbes would influence non-natives, we hypothesized that germination and growth of non-natives would be reduced in soils conditioned by heterospecific non-natives. The soil used to represent non-native mustards in this study was collected under another widespread mustard species $H$. incana (short-pod mustard), and not B. nigra. As such, how B. nigra may respond in soil conditioned by $B$. nigra plants remains untested. However, we observed that $B$. nigra germination (discussed above) and growth were reduced in unsterilized soil from both non-native soil origins-heterospecific-mustard and heterospecific-grass soil. While this partially supports our hypothesis, further testing of germination and growth of $B$. nigra in soil condition by B. nigra would allow us to make conspecific and heterospecific comparisons. Brassica spp. are known to be non-mycorrhizal and can inhibit fungal growth and spore germination $[34,38,39]$. Whether or not reductions in particular soil fungi in soil conditioned by $B$. nigra would enhance $B$. nigra germination and improve growth is unknown, but further studies should address whether $B$. nigra can, once established, alter soil conditions to enhance its germination rates. In contrast to B. nigra, B. madritensis growth was reduced in unsterilized conspecific soil relative to unsterilized heterospecific non-native soil. Potentially, species specific pathogen loads build up in B. madritensis soils, as the area we collected the soil from have been Bromus spp. dominated for at least 40 years. This further supports that idea that soil pathogens strongly influence plant-soil feedbacks in the sage scrub ecosystem. Increased growth of B. madritensis was partially expected in conspecific soil, as it has been found to contain higher concentrations of a fine mycorrhizal endophyte that colonizes $B$. madritensis facilitating nutrient transfer from the soil and enhancing growth [40]. Growth of the native shrub species, A. californica, and the other non-native annual species, B. nigra, was also reduced in unsterilized soil conditioned by $B$. madritensis relative to sterilized soil, indicating that soil pathogens may be generalists. Previous studies have explored how: (i) non-natives fare in soils conditioned by native species $[7,26,27]$, (ii) natives fare in non-native soils [7,27], and (iii) how natives fare in soils restored to native habitats after invasion [3], but as non-natives become more common, interactions among invasive species will become key to understanding how plant assemblage transitions influence plant soil-feedbacks, and potentially plant community structure, which is key to understanding bio-diversity [41] and other key ecosystem functions (e.g., litter decomposition and carbon storage [2,42]).

While it is presumed that plant-soil feedbacks are often driven by differences in soil microbe assemblages, other biotic and soil abiotic conditions are also modified when plant assemblages change $[27,43]$. As such, it can be difficult to ascertain how differences in soil microbial assemblages and other soil conditions interact to influence plant-soil feedbacks. For example, we were surprised that growth of all plant species was reduced in sage scrub soil despite having higher or equivalent concentrations of $\mathrm{N}$ and $\mathrm{C}$ (the two nutrients examined) to B. madritensis and B. nigra soil, respectively. However, Caspi et al. [2] found that sage scrub soil is more acidic than soils in non-native grasslands, with $\mathrm{pH}$ being lower in sage scrub by an average of 0.98 (range 1.36 to 0.66 ) compared to adjacent sage scrub soils. At the BFS, differences in $\mathrm{pH}$ are lower between habitats than recorded at other sites across southern California, but soil pH measurements in the A-horizon have been recorded as 6.00, $5.82,5.77$, and 5.68 in the grassland, and 5.54, 5.43. 5.25, and 5.11 in sage scrub $[1,2,4]$. Differences in $\mathrm{pH}$ can have significant impacts on many ecosystem processes, including carbon and nitrogen storage, litter decomposition, and N-cycling. The ecological implications associated with increasing $\mathrm{pH}$ on $\mathrm{N}$-cycling may explain why growth is low in sage scrub soil. Net nitrification is often lower in more acidic soils [44,45], and higher in soils with invasive grasses [46]. Enhanced nitrification often increases $\mathrm{N}$ loss by enhancing denitrification or leaching rates [13,47], providing a potential mechanism explaining reduced $\mathrm{N}$ concentrations in B. madritensis soil. Increases in nitrification 
can also result in greater plant-available $\mathrm{N}$, which can enhance plant-soil feedbacks, especially for non-native species that preferentially uptake nitrate over ammonium $[13,27,48]$, and potentially promote plant growth in B. madritensis soils to be equivalent with the acidic $A$. californica soils with higher concentrations of $\mathrm{N}$. Why all plants did better in B. nigra soils is unknown, but if $H$. incana reduces microbial abundances like other Brassica mustards [38,39], growth could be enhanced because less $\mathrm{N}$ is immobilized. Hirschfeldia incana soils did have low fungal concentrations relative to B. madritensis soils, but relatively similar concentrations to the more acidic $A$. californica soils. Another possible explanation for differences among soil types is allelopathy, though its importance remains controversial in the sage scrub ecosystem [49]. Artemisia californica, and other sage scrub shrubs, can produce allelopathic compounds (terpenes) that can be found in the soil and can restrict plant growth and germination of some species $[49,50]$. Terpenes and other allelopathic compounds become volatized when soils are wet, as occurs in these plant-soil feedback studies [50]. How these chemicals vary among seasons and sites, and how they are impacted by the autoclaving process was not examined here, but there is a chance that these chemicals could influence germination and growth, particularly in A. californica soils.

\section{Conclusions}

Our results contribute to a small but growing body of literature examining plant-soil feedbacks in the endangered California sage scrub ecosystem $[3,7,26,27]$, and demonstrate that plant-soil feedbacks depend on both the plant species identity and soil context. Though our findings suggest that: (i) A. californica soils can limit the establishment of some species (B. nigra) but not others (B. madritensis), (ii) conditions in A. californica soil restrict growth of all plants, and (iii) the two non-natives studied here are negatively impacted by soil microbes, but in some contexts can do better in heterospecific soil; they were often incongruent with other plant-soil feedback studies in the ecosystem. As such, we suggest that we are at the infancy of understanding these complex interactions in the sage scrub ecosystem. Future plant-soil feedbacks should include soils from multiple sites across the region and include microbiome sequencing techniques if we intend to develop a predictive framework for understanding plant-soil feedbacks for the sage scrub ecosystem. In addition, as we found significant reductions in germination rates for B. nigra in unsterilized soils, we recommend that incorporating germination, in addition to growth, could yield key insights into factors controlling plant assemblages $[6,9]$. Meanwhile, incorporating other abiotic and biotic factors (e.g., drought, N-deposition, herbivory, competition, fire) is critical to understanding the invasion success of non-native annuals and the resilience of native shrub populations in the sage scrub ecosystem $[7,23,51]$. A predictive framework for understanding plant-soil feedbacks across the ecosystem could improve restoration efforts and modeling the distributions of non-natives across the ecosystem, and the ecosystem ramifications of changes in plant assemblages $[1,2,4,15,36]$.

Author Contributions: Conceptualization, M.S. and W.M.M.III; methodology, M.S.; software, W.M.M.III; formal analysis, M.S. and W.M.M.III; investigation, M.S.; resources, W.M.M.III; data curation, M.S.; writing-original draft preparation, M.S.; writing - review and editing, W.M.M.III; visualization, W.M.M.III; supervision, W.M.M.III; project administration, W.M.M.III; funding acquisition, M.S. All authors have read and agreed to the published version of the manuscript.

Funding: This research was supported by the Jaquith Summer Fellowship from W.M. Keck Science Department of Claremont McKenna, Pitzer, and Scripps Colleges, the Robert J. Bernard Field Station, Pomona College Green House, and Pomona College Geology Department. We also thank Colin Robins for comments on early drafts.

Acknowledgments: We thank Lilliana Thomey and Kyra Madunich for assistance in the field and Jonathon Harris (Pomona College Geology Department) and Kyle McCarthy (Keck Science Department) who facilitated nutrient analysis. Soil was collected from the Robert J. Bernard Field Station.

Conflicts of Interest: The authors declare no conflict of interest. 


\section{References}

1. Caspi, T.; Estrada, L.; Dowling, A.V.; Su, E.; Leshchinskiy, M.; Cavalcanti, A.R.; Crane, E.J.; Robins, C.R.; Meyer, W.M. Carbon and nitrogen in the topsoils of Inceptisols and Mollisols under native sage scrub and non-native grasslands in southern California. Geoderma Reg. 2018, 14, 00172. [CrossRef]

2. Caspi, T.; Hartz, L.A.; Villa, A.E.S.; Loesberg, J.A.; Robins, C.; Meyer, W.M. Impacts of invasive annuals on soil carbon and nitrogen storage in southern California depend on the identity of the invader. Ecol. Evol. 2019, 9, 4980-4993. [CrossRef] [PubMed]

3. Pickett, B.; Irvine, I.C.; Bullock, E.; Arogyaswamy, K.; Aronson, E. Legacy effects of invasive grass impact soil microbes and native shrub growth. Invasive Plant Sci. Manag. 2019, 12, 22-35. [CrossRef]

4. Wheeler, M.M.; Dipman, M.; Adams, T.A.; Ruina, A.V.; Robins, C.R.; Meyer, W.M. Carbon and nitrogen storage in California sage scrub and non-native grassland habitats. J. Arid. Environ. 2016, 129, $119-125$. [CrossRef]

5. Bardgett, R.D.; Wardle, D.A. Aboveground-Belowground Linkages: Biotic Interactions, Ecosystem Processes, and Global Change; Oxford University Press: New York, NY, USA, 2010; p. 301.

6. Miller, E.C.; Perron, G.G.; Collins, C.D. Plant-driven changes in soil microbial communities influence seed germination through negative feedbacks. Ecol. Evol. 2019, 9, 9298-9311. [CrossRef] [PubMed]

7. Yelenik, S.; Levine, J.M. The role of plant-soil feedbacks in driving native-species recovery. Ecology 2011, 92, 66-74. [CrossRef]

8. Chambers, J.C.; Miller, R.F.; Board, D.I.; Pyke, D.; Roundy, B.A.; Grace, J.B.; Schupp, E.W.; Tausch, R.J. Resilience and Resistance of Sagebrush Ecosystems: Implications for State and Transition Models and Management Treatments. Rangel. Ecol. Manag. 2014, 67, 440-454. [CrossRef]

9. Connolly, B.M.; Carris, L.M.; Mack, R.N. Soil-borne seed pathogens: Contributors to the naturalization gauntlet in Pacific Northwest (USA) forest and steppe communities? Vegetation 2018, 219, 359-368. [CrossRef]

10. D'Antonio, C.M.; Thomsen, M. Ecological Resistance in Theory and Practice1. Weed Technol. 2004, 18, 1572-1577. [CrossRef]

11. Han, X.; Dendy, S.P.; Garrett, K.A.; Fang, L.; Smith, M.D. Comparison of damage to native and exotic tallgrass prairie plants by natural enemies. Vegetation 2008, 198, 197-210. [CrossRef]

12. Reinhart, K.O.; Callaway, R.M. Soil biota and invasive plants. New Phytol. 2006, 170, 445-457. [CrossRef] [PubMed]

13. Hawkes, C.V.; Wren, I.F.; Herman, D.J.; Firestone, M.K. Plant invasion alters nitrogen cycling by modifying the soil nitrifying community. Ecol. Lett. 2005, 8, 976-985. [CrossRef]

14. Suding, K.; Gross, K.L.; Houseman, G.R. Alternative states and positive feedbacks in restoration ecology. Trends Ecol. Evol. 2004, 19, 46-53. [CrossRef] [PubMed]

15. Pickett, B.; Maltz, M.; Aronson, E. Impacts of Invasive Plants on Soil Fungi and Implications for Restoration. In Diversity and Ecology of Invasive Plants; IntechOpen: London, UK, 2019; pp. 1-18.

16. Allen, T.A.Z.R.F. The Effects of Organic Amendments on the Restoration of a Disturbed Coastal Sage Scrub Habitat. Restor. Ecol. 1998, 6, 52-58. [CrossRef]

17. Cox, R.D.; Allen, E. Stability of exotic annual grasses following restoration efforts in southern California coastal sage scrub. J. Appl. Ecol. 2008, 45, 495-504. [CrossRef]

18. Rundel, P.W. Sage Scrub. In Terrestrial Vegetation of California; Barbour, M.G., Keeler-Wolf, T., Schoenherr, A., Eds.; University of California Press: Berkeley, CA, USA, 2007; pp. 208-228.

19. Talluto, M.V.; Suding, K. Historical change in coastal sage scrub in southern California, USA in relation to fire frequency and air pollution. Landsc. Ecol. 2008, 23, 803-815. [CrossRef]

20. Lambert, A.M.; D'Antonio, C.M.; Dudley, T.L. Invasive species and fire in California ecosystems. Fremontia 2010, 38, 29-36.

21. Minnich, R.A.; Dezzani, R.J. Historical decline of coastal sage scrub in the Riverside-Perris Plain, California. West. Birds 1998, 29, 366-391.

22. Valliere, J.M.; Bucciarelli, G.M.; Bytnerowicz, A.; Fenn, M.E.; Irvine, I.C.; Johnson, R.F.; Allen, E.B. Declines in native forb richness of an imperiled plant community across an anthropogenic nitrogen deposition gradient. Ecosphere 2020, 11, e03032. [CrossRef]

23. Kimball, S.; Goulden, M.; Suding, K.; Parker, S. Altered water and nitrogen input shifts succession in a southern California coastal sage community. Ecol. Appl. 2014, 24, 1390-1404. [CrossRef] 
24. D'Antonio, C. Biological Invasions by Exotic Grasses, the Grass Fire Cycle, and Global Change. Annu. Rev. Ecol. Syst. 1992, 23, 63-87. [CrossRef]

25. Keeley, J.; Brennan, T.J. Fire-driven alien invasion in a fire-adapted ecosystem. Oecologia 2012, 169, $1043-1052$. [CrossRef] [PubMed]

26. Bozzolo, F.H.; Lipson, D.A. Differential responses of native and exotic coastal sage scrub plant species to N additions and the soil microbial community. Plant Soil 2013, 371, 37-51. [CrossRef]

27. Valliere, J.M.; Allen, E.B. Nitrogen enrichment contributes to positive responses to soil microbial communities in three invasive plant species. Biol. Invasions 2016, 18, 2349-2364. [CrossRef]

28. Kulmatiski, A. Factorial and 'self vs. other' plant soil feedback experiments produce similar predictions of plant growth in communities. Plant Soil 2016, 408, 485-492. [CrossRef]

29. Fortune, P.M.; Pourtau, N.; Viron, N.; Ainouche, M.L. Molecular phylogeny and reticulate origins of the polyploid Bromusspecies from section Genea(Poaceae). Am. J. Bot. 2008, 95, 454-464. [CrossRef]

30. Spear, D.; Adams, T.A.; Boyd, E.S.; Dipman, M.; Staubus, W.J.; Meyer, W.M. The effects of development, vegetation-type conversion, and fire on low-elevation Southern California spider assemblages. Invertebr. Biol. 2017, 10, 1230. [CrossRef]

31. Fenn, M.; Haeuber, R.; Tonnesen, G.; Baron, J.S.; Grossman-Clarke, S.; Hope, D.; Jaffe, D.A.; Copeland, S.; Geiser, L.; Rueth, H.M.; et al. Nitrogen Emissions, Deposition, and Monitoring in the Western United States. Bioscience 2003, 53, 391. [CrossRef]

32. Sigüenza, C.; Crowley, D.; Allen, E.B. Soil microorganisms of a native shrub and exotic grasses along a nitrogen deposition gradient in southern California. Appl. Soil Ecol. 2006, 32, 13-26. [CrossRef]

33. Schnürer, J.; Rosswall, T. Fluorescein Diacetate Hydrolysis as a Measure of Total Microbial Activity in Soil and Litter. Appl. Environ. Microbiol. 1982, 43, 1256-1261. [CrossRef]

34. Marushia, R.G.; Brooks, M.L.; Holt, J.S. Phenology, Growth, and Fecundity as Determinants of Distribution in Closely Related Nonnative Taxa. Invasive Plant Sci. Manag. 2012, 5, 217-229. [CrossRef]

35. Anderson, M.J.; Gorley, R.N.; Clarke, K.R. PERMANOVA+ for PRIMER: Guide to Software and Statistical Methods; PRIMER-E Ltd.: Plymouth, UK, 2008.

36. Castro, S.P.; Cleland, E.E.; Wagner, R.; Al Sawad, R.; Lipson, D.A. Soil microbial responses to drought and exotic plants shift carbon metabolism. ISME J. 2019, 13, 1776-1787. [CrossRef] [PubMed]

37. Dickens, S.J.M.; Allen, E.B.; Santiago, L.S.; Crowley, D. Extractable nitrogen and microbial community structure respond to grassland restoration regardless of historical context and soil composition. AoB Plants 2015, 7, 7. [CrossRef] [PubMed]

38. Pakpour, S.; Klironomos, J. The invasive plant, Brassica nigra, degrades local mycorrhizas across a wide geographical landscape. R. Soc. Open Sci. 2015, 2, 150300. [CrossRef]

39. Schreiner, R.P.; Koide, R.T. Mustards, mustard oils and mycorrhizas. New Phytol. 2006, 123, $107-113$. [CrossRef]

40. Sigüenza, C.; Corkidi, L.; Allen, E. Feedbacks of Soil Inoculum of Mycorrhizal Fungi Altered by N Deposition on the Growth of a Native Shrub and an Invasive Annual Grass. Plant Soil 2006, 286, 153-165. [CrossRef]

41. Staubus, W.J.; Boyd, E.S.; Adams, T.A.; Spear, D.; Dipman, M.; Meyer, W.M. Ant communities in native sage scrub, non-native grassland, and suburban habitats in Los Angeles County, USA: Conservation implications. J. Insect Conserv. 2015, 19, 669-680. [CrossRef]

42. Dipman, M.M.; Meyer, W.M. Type conversion from native California sage scrub to non-native grassland accelerates decomposition processes. Appl. Soil Ecol. 2019, 144, 68-71. [CrossRef]

43. Bennett, J.A.; Klironomos, J. Mechanisms of plant-soil feedback: Interactions among biotic and abiotic drivers. New Phytol. 2018, 222, 91-96. [CrossRef]

44. Haynes, R. Nitrification. In Mineral Nitrogen in the Plant-Soil System; Haynes, R., Ed.; Academic Press: New York, NY, USA, 1996; pp. 127-165.

45. Sahrawat, K.L. Nitrification in some tropical soils. Plant Soil 1982, 65, 281-286. [CrossRef]

46. Dickens, S.J.M.; Allen, E.B. Soil nitrogen cycling is resilient to invasive annuals following restoration of coastal sage scrub. J. Arid Environ. 2014, 110, 12-18. [CrossRef]

47. De Boer, W.; Hundscheid, M.P.J.; Schotman, J.M.T.; Troelstra, S.R.; Laanbroek, H.J.; Boer, W. In situ net $\mathrm{N}$ transformations in pine, fir, and oak stands of different ages on acid sandy soil, 3 years after liming. Biol. Fertil. Soils 1993, 15, 120-126. [CrossRef] 
48. Sperry, L.J.; Belnap, J.; Evans, R.D. Bromus Tectorum Invasion Alters Nitrogen Dynamics in an Undisturbed Arid Grassland Ecosystem. Ecology 2006, 87, 603-615. [CrossRef] [PubMed]

49. Halsey, R.W. In Search of Allelopathy: An Eco-Historical View of the Investigation of Chemical Inhibition in California Coastal Sage Scrub and Chamise Chaparral. J. Torrey Bot. Soc. 2004, 131, 343. [CrossRef]

50. Halligan, J.P. Toxic Terpenes from Artemisia Californica. Ecology 1975, 56, 999-1003. [CrossRef]

51. Litle, J.; Quon, L.H.; Antill, M.L.; Questad, E.J.; Meyer, W.M. Vertebrate herbivory on shrub seedlings in California sage scrub: Important but understudied interactions. Vegetation 2019, 220, 523-528. [CrossRef]

(C) 2020 by the authors. Licensee MDPI, Basel, Switzerland. This article is an open access article distributed under the terms and conditions of the Creative Commons Attribution (CC BY) license (http://creativecommons.org/licenses/by/4.0/). 